\title{
Panel Discussion The Politics of Truth in Education and the Public Space: Discussion at the Opening of the Volume
}

\section{Marek Czyżewski}

University of Lodz, Poland

Ewa Marynowicz-Hetka

University of Lodz, Poland

\section{Maria Mendel}

University of Gdańsk, Poland

\section{Ryszard Mordarski}

Kazimierz Wielki University, Poland

\section{Helena Ostrowicka}

Kazimierz Wielki University, Poland

\section{Cezary Rudnicki}

Independent Scholar, Poland

Marek Czyżewski is a Professor at the Institute of Sociology and Head of the Department of Research on Social Communication, University of Lodz, Poland. His main interests include: discourse analysis; public and mass communication; public opinion and democracy; hate speech; "govern- mentality"; intercultural and international communication; social theory (especially interpretive approaches, sociology of knowledge, and Foucault). Editor-in-chief of "Przegląd Socjologiczny"; editor of the series Biblioteka Dyskursu Publicznego. email address: marek.czyzewski@uni.lodz.pl 
Ewa Marynowicz-Hetka is a social pedagogue, Professor of Humanities, D.H.C. of the University of Ostrava (Czech Republic), Head of the Department of Social Pedagogy at the University of Lodz (1987-2019), member of the Pedagogy Sciences Committee of the Polish Academy of Sciences (2003-2011), Editor-in-chief of the journal "Educational Sciences. Interdisciplinary Studies." Her research interests are: reflection on the basis of social pedagogue in the field of practice; training for social professions and action in the field of social/societal work; associations of social pedagogy with social work, understood as an area of activity; epistemological and methodological issues of social comprehension as a discipline and as the orientation of social activity. The author of many books and articles on these topics. She is the author of the book Social Pedagogy, Comprehending Activity in the Field of Practice (LAMBERT Academic Publishing, 2020).

email address: ewa.marynowicz@uni.lodz.pl

Maria Mendel is a Professor at the University of Gdańsk, Chair of the Department of Social Pedagogy, Faculty of Social Sciences, Institute of Education. She is interested in social pedagogy as critically oriented pedagogical thinking about the human-world relationship, especially in regards to local communities, parents, and teachers. For years, she has been developing the area of research and educational practice known as the pedagogy of place. The latest research projects concern the pedagogy of the city, including "Miasto jako wspólny pokój" ("The City as the Shared Room"), "Gdańsk według dzieci. Dziecięce geografie na rzecz spójności społecznej miasta" ("The ways children see Gdansk. Children's geographies for the city's social cohesion)." Recently published books: Pedagogika miejsca wspólnego. Miasto i szkoła (Pedagogy of the Shared Place. The City and the School [2017]); Miasto dla sztuki. Sztuka dla miasta (City for Art. Art for the City [2018, co-ed.]); Pamięć i miejsce (Memory and Place [2019, co-ed.]); Eduwidma. Rzeczy i miejsca nawiedzone (Edu-Specters. Things and Haunted Places [2020, ed.]).

email address: pedmm@ug.edu.pl
Ryszard Mordarski is a PhD, Hab., Associate Professor in the Institute of Philosophy, Kazimierz Wielki University in Bydgoszcz, Poland. His research areas are: philosophy of politics, ethics, and philosophy of religion. His recent publications: "Probabilistic Theism and the Traditional Doctrine of Actus Purus," Roczniki Filozoficzne, no. 3(LXVIII), 2020, pp. 187-203; “Józef M. Bocheński's Conception of Analytic Philosophy," Heteroglossia, no. 9, 2019, pp. 245-256. He is also a translator of philosophical literature from English into Polish. He recently translated: John L. Schellenberg, Argument z ukrytości, Bydgoszcz, 2019 (J. L. Schellenberg, The Hiddenness Argument, Oxford University Press, 2015).

email address: rmordarski19@ukw.edu.pl

Helena Ostrowicka is a PhD, Hab., Associate Professor, Dean of the Faculty of Pedagogy, and Head of the Department of Research Methodology and Discourse Studies at Kazimierz Wielki University in Bydgoszcz, Poland. Her research areas are: policy and educational discourse analysis, reception of Foucauldian ideas in educational research, science and higher education policy, discourses on the youth and citizenship. She is the author of five monographs (i.a., Regulating Social Life: Discourses on the Youth and the Dispositif of Age 2019, Palgrave Macmillan; co-author: The Dispositif of the University Reform. The Higher Education Policy Discourse in Poland, 2020, Routledge) and many articles published, among others, in Discourse: Studies in the Cultural Politics of Education, Educational Philosophy and Theory, Higher Education Research \& Development, European Educational Research Journal.

email address: hostrowicka@ukw.edu.pl

Cezary Rudnicki is a doctor of philosophy. His doctoral dissertation concerned the ethical concepts of Foucault and Deleuze and Guattari. His research interests are: ontology, ethics, social philosophy, and the diagnosis of topicality.

email address: c.rudnicki@ecs.gda.pl 


\section{Participants: Marek Czyżewski, Ewa Marynowicz-Hetka, Maria Mendel, Ryszard Mordarski, Cezary Rudnicki}

\section{Host: Helena Ostrowicka}

Helena Ostrowicka: The pretext for today's discussion panel are the lectures of Michel Foucault which are devoted to the practices of producing and manifesting truth.

This year we have an excellent opportunity to come back to these lectures on account of significant publishing events. First of all, a Polish edition of lectures in the Collège de France and Louvain was published, where the French philosopher tackled the issues of truth, veracity, and avowal. These are the collections entitled "The Government of Self and Others," published by PWN, and a book entitled "Wrong-Doing, Truth-Telling. The Function of Avowal in Justice," published by Znak. Secondly, a Polish edition of François Noudelmann's book, "The Genius of Lies," was published in September, in which one of the discussed issues is Foucault's "courage of lies."

To start the discussion on the politics of truth in education and the public space, I am going to paraphrase the words of Foucault from a lecture given on January 14, 1976.

General problems may be worded as follows: to which rules, embedded in the educational and the public sphere, does the authority resort in order to create a discourse of truth? What kind of power is capable of generating discourses of truth in education and public space?

First of all, I would like to ask Professor Marek Czyżewski to speak.
Marek Czyżewski: I venture to say that examining the issue of the discourse of truth today requires a revision of Foucault's perspective. As is known, Foucault's works, from the beginning to the end of his scientific activity, feature two threads: on the one hand, there is the problem of power (later, the problem of governmentality), and on the other hand, there is the problem of knowledge (as well as the will to knowledge, regimes of truth, later acts of truth, and, in particular, acts of avowal and parrhesia, that is, truth-telling). Foucault always combined these two threads and treated them as intertwined. This is the key content contained in his research perspective, so far associated with a neologism proposed by Foucault, namely, "power-knowledge." During the lectures of 1979/1980, Foucault changed the terminology, but he continued to follow the traces of his fundamental conviction, and now he speaks about the inseparable relation of the exercise of power with the manifestations of truth.

Thus, I believe that the first of the aforementioned threads, that is, Foucault's understanding of power (and governmentality), still remains valid. However, it is worth considering whether the modern forms of governmentality are always related to the determination, or expression of truth. And thus: does Foucault's axiom (conviction about the inevitable convolution of power and truth-establishing practices) stand the test of time in the conditions of contemporary culture? Insofar as Foucault showed an exceptional gift of foresight with respect to the transformation of relations of power in the direction of the ruling, in my opinion, he failed to sense the direction of cultural changes with respect to the indifference to the truth, that is, in the direction of phenomena called post-truth and regimes of posttruth (this last term was proposed by Jason Harsin). Harry Frankfurt's essay "On Bullshit" is also in- 
structive with respect to the indifference to truth. The essay was written in the 1980s, but its relevance is on the rise today.

I would like to put forward a thesis which is a heresy from Foucault's point of view: today, we are dealing with governmentality with simultaneous progressing indifference to the issue of the truthfulness of messages, that is, to put it briefly: governmentality without truth. ${ }^{1}$

When talking about regimes of post-truth, I do not have in mind the herd instinct of journalists approximately 2-3 years ago with respect to the excessive use of the term "post-truth." Fortunately, this trend has passed. Here, I have in mind a significant cultural transformation which consists in the fact that the value of more and more numerous and less and less inter-related messages in the public space is not determined on the basis of the criterion of their truth, but on the basis of whether such messages are capable of catching our attention, stirring our emotions, and matching our convictions. Here, I would like to warn you against the book by Ralph Keyes entitled "The Post-Truth Era" of 2004. Even though Keyes was one of the promoters of the term "post-truth," he related it to the multiplication of lying practices. Thus, Keyes read today offers us completely erroneous clues. It is because post-truth (as we know it today) does not consist in lying (that is, a conscious negation of truth, hidden from the recipients), but in weakening or rejecting the serious treatment of the criterion of truth. As for this issue, the above-mentioned earlier text by Frankfurt (written in the 1980s) hits the nail right on the head. At that time, Frankfurt

\footnotetext{
${ }^{1}$ A more extensive explication and an attempt at justifying this thesis are contained in my article entitled "Governmentality without Truth" (in this issue).
}

analyzed the phenomenon of "bullshitting," that is, the phenomenon of formulating a message and simultaneously hiding the fact by the sender that it is all the same to him/her whether he/she is telling the truth or not. The notion of bullshitting also has features convergent with the phenomenon of posttruth, yet in the case of post-truth, the indifference to the criterion of truth also refers to the recipients of the message. Obviously, this does not negate the fact-at least in my opinion-that parrhesia is still very important, yet a normative idea, similarly to Foucault's belief. On the other hand, it would be difficult to treat the concept of parrhesia as an analytical category which would allow us to examine the more popular communication practices. Here, my doubts are very serious.

It seems to me that more accurate inspirations in the area of basic theses about cultural transformations may be found in the slightly forgotten concepts of Baudrillard, and in particular in his distinction between what is symbolic, that is, what is important for us, what gives us the feeling of sense, and refers to the seriously treated, collective symbolism, and into what is semiotic, that is, what is sent and received from the public space, without attaching importance to it. Here, we are dealing with the "implosion of meaning," the swamping of our civilization by ourselves with a mass of messages; the more messages, the less sense in them, and their significance for us is less and less frequent. As we know, Baudrillard argued with Foucault with respect to power; he believed that in post-modernity, relations of power are subject to virtualization. It is possible that today he would take a position different than Foucault's and the position sketched here, and he might conclude that not only are we dealing with indifference to the issue of truth, but also with the disappearance of governmentality. 
It also seems to me that the reception of Bernard Stiegler would be very important; his idea of psychopower, the managing of our mentality, our attention, and in consequence the phenomenon of stupidity on a mass scale.

Thus, a need arises for a potentially quite risky synthesis of various threads deriving from different concepts. I am under the impression that the problem of power in Foucault's approach is very valuable and worth delving into, but I still believe that Stiegler's ideas about psychopower, and not only biopower, should be combined with it. On the other hand, as I have mentioned before, Foucault did not sense the direction of changes in culture correctly.

However, if we wanted to derive any form of normative ethics from the analysis of reality, then I believe that we could revert to Foucault via the category of desubjectification (déassujettissement), mentioned briefly in one occasional interview, and by referring it to truth-telling. I believe that uncompromising engagement in parrhesia is very often quite valuable. However, it is worth remembering that submission to authority is not necessarily placed on the opposite side. There is also such a value as tact. There is also such a value as a commendation of inconsistency. There is also such a value about which Foucault talks in a text about the identity politics of the gay community, and Wendy Brown progresses it: complete identification with a community important for oneself, with which Foucault identified, leads to being trapped in an intellectual rut and rigidity of action. Thus, the idea of parrhesia is also burdened with limitations: namely, when parrhesia becomes a community voice and is thereby subject to routinization and schematization.

Therefore, it seems worth searching for a synthesis of various threads, which, in my opinion, does not necessarily lead to eclecticism, but rather to limited trust in certain authors. I would like to finish here.

Ewa Marynowicz-Hetka: While getting ready to speak, I once again started to look at various proposals of Foucault from the perspective of educational space, among others also reaching for the French edition of his lectures at Berkeley and discussions at this university (Lorgine de l'hermenéutique de soi, Conférences prononcées à Dartmounth College, 1980 [2013]), as well as the interview with Michael Bess. It is known that the normative factor is very strong in education. It is also possible to put forward a strong thesis that, in principle, there is no education without a normative dimension. Thus, the question arises of whether it is possible to find any justification or opposition in Foucault's views in relation to the practice of truth in the educational space. This was the task that I set for myself.

Du gouvernement des vivants (2012) includes a very strong thesis about the examination of regimes of truth, which Foucault understands as relations linking the truth-revealing acts with subjects. If we assume that education, whatever happens in the area of education, is a certain set of actions, then, obviously, the subjects of these actions are very important, but particularly important are the mutual relations of the subject with whatever happens in such a space. If so, then while studying this public debate (sur la vérité et subjectivité) in Berkeley (23 October 1980), I noted with surprise that Foucault straightforwardly formulates such theses that sometimes seem too radical to me. For example, the category of stance and the category of non-obvious suspension of power are very clear in revealing the truth. Every time a subject appears here. In my opinion, this is also very interesting for a teacher who wants to develop such thinking. This is such a stance: this is me, this is me speaking, and thus I have the truth. 
If this stance is transferred, for example, to the level of educational relations, then it seems to me that here we can treat it as a certain element of an analytical tool. Yet, my question is: could it be treated this way? First and foremost, due to the fact that in the French language (but not only there) there are three categories of "I": je (I), moi (ipselego) and soi (I-myselfl idem, or selfhood in Ricoeur's translation into English [2003]). In reference to the relations between the regimes of truth with the educational space, this third category, soi, is very important, as it is related to the activity; it constitutes-as specified by Jean-Marie Barbier (2016) - the product of perceiving oneself as the acting subject. Foucault specifies what refers to soi and determines that I can also conduct myself. In response to one of the questions during the discussion in Berkeley, Foucault provides this example: as a father, I have a right to hit the child (as a side note, the 1980s, when it was still possible, are clearly noticeable here), but I do not do it, thence I influence myself. Here, I used the term influence, but in Foucault's language, the term conduite/conduire, conduire de soi-même, is used, that is, to conduct oneself. Yet, I believe that in the mental or emotional sense, or the affective sense-because this is the most frequent type of acting-in this register, subjectivity (subjectivité) is understood as a relation to oneself (soi à soi).

I remember the discussions during our post-Foucault seminar when we analyzed Foucault's category of subject. I saw this dilemma differently. While reading this public discussion with the participation of Foucault, I discovered where subjectivité (subjectivity) means the attitude to oneself, the conduct of oneself. This may be interpreted in a manner that my internal powers are directing me-my activities, my reactions. On the other hand, the relation of power is a relation between me (myself) and others.
So, here we have a very clear ethical dimension of this relation, marked very strongly at this moment. For example, it is said that knowledge is the relation between two persons. Obviously, in the sense that it has to be communicated somehow, it has to be uttered, but it also covers the entire scope of knowledge that is not uttered at all, non-verbalized. This set, these relations are never balanced. They are unbalanced by principle, says Foucault. If so, then the teacher can ask a question: then what about relations of reciprocity, which are so important in the educational space? For example, the philia, partage-type relation. In almost all educational texts-the classical ones-these categories are also emphasized in anthropological approaches. If we take, as the starting point, Foucault's stance that the relation with the Other is always unbalanced, that it is often impossible to determine the status of its power directly, then subsequent problems will appear. We discussed this issue and we have probably concluded that this is not a linear sequence, but that there is always a certain junction, or-using the metaphor of Bogdan Nawroczyński (1947) - a braid of such intertwined situations and in this case also types of relations. But-as Foucault said-if we are using a phrase like: "I wish for," or "I want," we are already creating a relation of power. I think that this is a guideline for teachers, for entities operating in the educational space, as such situations are very frequent. Obviously, this is also included in the broad phenomenon of pedagogization.

One more thing: I do not want to take too long, but there is one thing that seems very accurate in the context of building relations with respect to potential further thinking. This is the third dimension of "I" about which Foucault talks, that is, soi (me-myself, idem, selfhood): when he says that it is revealed in the examination of conscience and in confession. When he talks about the genealogy of oneself, that 
is a situation when I wonder what (and how) has changed. Somebody from the audience asks a question: is this (soi) a soul? And Foucault explains: no. This is a type of relationship where the human being as a subject may retain the relation with itself. We are not entering this level here. In this context, governing or management is a technique, Foucault says, which may be used for self-development, self-conduct, and leading people with the aim of domination. The main purpose is domination, which he introduces to the relation in a sophisticated manner, not straightforwardly. In any case, it is known that this is done through all the tactics and strategies that he talks about. Here, I am wondering whether this is already objectification; quite a lot has been written about reification, as well as commodification (fr. marchandisation) of relations, or maybe not yet: is it a certain unmasking of relations of this type, which constitute such desired relations in the educational space?

Maria Mendel: Dear Professor, after such a speech it is difficult to join this extremely wealthy reflection, and I am quite at a loss as to where to start. Professor Czyżewski greatly forestalled me. Things that have been said at the beginning have actually exhausted everything that I wished to talk about. So as not to repeat anything, I will talk about some other issues. The plan was that in response to the summoning of the panel on the politics of truth in the education of the public space, I would first draw attention to how the politics of truth in today's reality has been incorporated into such a formula of theoretical practice in which we are dealing neither with truth nor with actual politics. These threads were pursued in earlier speeches, and I will revert to them without completely abandoning this perspective, but I will start with something else, which is probably going to completely ruin my synopsis.
In 1967, Foucault wrote a brief yet well-known text about heterotopia, entitled "Of Other Spaces" ("Des espaces autres"). In the beginning, he claims that the time has come when great narratives are in the past: "the time of time" has passed, and we are entering the time of space. On the basis of this introduction, he constructs his stance about other spaces, different ones. It seems that when talking about the growing rank of space, he manifested great intuition. When we look at the vast expanse of repartition practices and the forms in which they are observed today, described by Foucault as organized management and manipulation of people consisting in their relocation already in Discipline and Punish; when we become aware that this process has become global, for example, in cities which become similar through the same patterns of expropriation supporting the accumulation of capital (as we talked about during the discussion yesterday, and a bit today in the lobby, referring to Harvey), then, definitely, Foucault is prophetically right. Yet, on the other hand, Foucault is slightly lacking intuition. He did not have the foresight to predict that the time of space would become the time of space of memory; that space would be dominated by the past time, which would absolutely format it. And this is happening in front of our very eyes; this is our "here and now." We create space on the basis of the "principle of the past," where the figure of return is of key significance. We are talking about the contemporary past's turn (or "U-turn"). It is easily noticeable that the return today organizes everything, including the past. Putting it forward as a thesis for our speech, I will also draw attention to two dates: 1997 and 2017. In 1997, Paulo Freire died, having handed over his last book, Pedagogy of the Heart, for printing. In 2017, Zygmunt Bauman died, and in this year his book entitled Retrotopia appeared, without him seeing a single published copy. These two dates, divided by twenty years, and the content of the books, make 
you think when you try to look at today's reality dominated by the past from the social, educational, and political point of view. In his Pedagogy of the Heart, Freire raises the alarm: be warned of the future which is the past. Be careful of it. Build the future differently, not on the principle of return. We read Bauman's Retrotopia with a similar impression; already in the introduction, the author talks about the effect of return; about a stubborn return, which characterizes the contemporary flights to the future; about a return which-given the shared fear of what is going to happen-becomes the only way. Being afraid of the future, we prefer to return to what is behind us and rely on the construction of the common world on fearbased maniacal retro-activity. Retromania creates retro-toposes: culture, education, economy, society, about which we can primarily say that they have a past. Under the slogan of retrotopia, Bauman, in principle, describes what becomes the increasingly stronger, globally shared principle of social life in the face of the depth of the experienced crisis and blocking of the future as its consequence. Timothy Snyder in principle says the same both in On Tyranny and in The Road to Un-Freedom, while writing about the modern prevalence of "anti-history." His notions converge with Bauman's in particular when he draws attention to how safe we felt in the neo-liberal formatting, believing that the future-subject to the same laws as the entire reality-was, to a significant degree, foreseeable. If the excellence of the principle of the free market was acknowledged, then, in consequence, this also encompassed the thought about the future. In brief, until the collapse of neo-liberalism on the economic level, that is, until the time of the crisis of 2008, we knew more or less what the future would be like, and in relation to this, we approached it without any greater fear. Yet neo-liberalism, with its unshaken faith in the free-market formula, has been quickly exhausted by the economic crisis. As Doreen Massey claims, it persists on the ideological level, because it grew into our minds and hearts like an ethos, but the collapse of the vision of a better future supposedly guaranteed by the consequence of the dominant principle simply turned the axis, and it is no longer the future, but the past that is formatting our world today. In reference to our discussion, Doctor Maksymilian, is it not some kind of a formula of benefiting from the practice of enchanting the world anew? In defiance and in opposition to the constantly experienced infinity of the $19^{\text {th }}$-century project of modernization of the world? I am making an obvious reference to Weber's "disenchantment of the world," in other words, also "the format" with respect to which both this neo-liberal project and the one that is implemented today came into being. So, possibly, the modern "enchantment" is the tightening loop of return, looping of the world towards the past. More and more ominous "war-smelling" nationalism is born out of this looping, somehow in front of our eyes, day after day. The only thing that we are capable of believing after the faith in a better world has collapsed is the faith in the re-born power of our own nation. Everybody knows Trump's slogans ("Make America Great Again"), Kaczyński's words about the “Great Jagiellonian Poland," or Orban's dreams about the new power of Hungary. Emergency exits? While looking for them, we will reach for Foucault and education in the public space. The discourse of the race struggle, historically contextualized by Foucaultderiving not so much from its contestation, but from the bifurcation that took place in the $19^{\text {th }}$ century-the discourse of the class struggle led the author to the conclusion that "society must be defended." ${ }^{2}$ During a lecture at the Collège de France on January 21, 1976, he said (I will take the liberty of presenting the full

\footnotetext{
${ }^{2}$ Foucault, Michel. 1998. Society Must Be Defended. Lectures at the Collège de France. Polish translation by Małgorzata Kowalska. Warsaw: Wydawnictwo KR, pp. 68-70 et seq.
} 
quote, which is quite lengthy): “In other words, what we see as a polarity, as a binary rift within society, is not a clash between two distinct races. It is the splitting of a single race into a super-race and a sub-race. To put it a different way, it is the reappearance, within a single race, of the past of that race. In a word, the obverse and the underside of the race reappears within it. This has one fundamental implication: the discourse of race struggle-which, when it first appeared and began to function in the seventeenth century, was essentially an instrument used in the struggles waged by decentered camps-will be recentered and will become the discourse of power itself. It will become the discourse of a centered, centralized, and centralizing power. It will become the discourse of a battle that has to be waged not between races, but by a race that is portrayed as the one true race, the race that holds power and is entitled to define the norm, and against those who deviate from that norm, against those who pose a threat to the biological heritage. At this point, we have all those biological-racist discourses of degeneracy, but also all those institutions within the social body which make the discourse of race struggle function as a principle of exclusion and segregation and, ultimately, as a way of normalizing society. At this point, the discourse whose history I would like to trace abandons the initial basic formulation, which was: 'We have to defend ourselves against our enemies because the State apparatuses, the law, and the power structures not only do not defend us against our enemies; they are the instruments our enemies are using to pursue and subjugate us.' That discourse now disappears. It is no longer: 'We have to defend ourselves against society,' but 'We have to defend society against all the biological threats posed by the other race, the sub-race, the counter-race that we are, despite ourselves, bringing into existence.' At this point, the racist thematic is no longer a moment in the struggle between one social group and another; it will promote the global strategy of social conservatisms. At this point-and this is a paradox, given the goals and the first form of the discourse I have been talking about-we see the appearance of a State racism: a racism that society will direct against itself, against its own elements and its own products. This is the internal racism of permanent purification, and it will become one of the basic dimensions of social normalization." ${ }^{3}$ State racism "takes place" in a public space which-irrespective of the fact that it is retro-topical today because it is constructed according to the principle of return to the past-remains deeply educational. And the non-reducible element of thinking about education is its relational nature and location (locus educandi). Most generally, education is what happens "between" and "elsewhere." These are the exact terms that may be used to describe the public space. Education is created in reciprocity, when every gesture in the established relationship meets with another one, deriving from the "other side." Thus, for example, Gert Biesta writes about various forms of public education and "out of concern for the society" displays public education which seems to break-characteristic for state racism - the rule of searching for and identifying an enemy based on looped returns to the post-truths of the past. Such public education focused not on the formation of patriots by adjusting them to the specific, politically utilitarian mold, but on allowing for activities and fostering conditions for the emergence of individual and social freedom. This is education which, through, for example, Rancièr-like interruptions, allows for breaking the ties which create a public space in a shape non-acceptable for a given individual or a group. This means entering into such relations which would be an expression of the possi-

\footnotetext{
${ }^{3}$ Foucault, Michel. 1998. Society Must Be Defended. Lectures at the Collège de France. Polish translation by Małgorzata Kowalska. Warsaw: Wydawnictwo KR, pp. 69-70.
} 
bility of acting and would offer a feeling of freedom. Such a break may form the subjective formula of being possessed by the past, described a moment ago. This simultaneously stops the modern state racism, which may be manifested in constantly competitive and infinite "standing out," not so much of the race from the past, but the continually new past from the uniform, state race which is searching for an enemy outside of itself. Obviously, this is not a recipe, but it is worth noting that what I talked about we have learned from Foucault. Foucault is-once again and infinitely-educational.

Helena Ostrowicka: I would like to thank you very much for these inspiring voices. Before I hand over the microphone to other participants of our meeting, I would like to ask an open question pertaining to the discussion: to which degree may the category of psychopower, which was mentioned by Professor Czyżewski, be reconciled with the category of avowal, if we assume that avowal is the practice of being liable for speaking about oneself? Do we still, I believe that we do, live in a confessing society, as Foucault said one day? In such a case, aren't these elements from Foucault's lectures combined with the above-mentioned category of psychopower?

\section{Marek Czyżewski: Should I say something?}

\section{Helena Ostrowicka: Yes. Please do.}

Marek Czyżewski: In this case, I will try to refer to this issue on the spur of the moment. I have the impression that we are circling around the need for new terms. And your question, Helena, also seems to be leading to this issue. I will give you an example, which will (hopefully) illustrate what I have in mind. A long time ago, a book entitled The Spectacle of History was written by two ethnomethodologists: the most important student of Harold Garfinkel, Michael Lynch, and David Bogen. The book was devoted to the sessions of the congressional committees investigating the famous "Iran-Contra" affair. In the context of analyzing the public hearings of this committee, which in any case resemble the sessions of our parliamentary committees, the authors state a thing that we are also familiar with: namely, such committees never reach the truth, and in any case-in spite of the fact they will talk about reaching the truth all the time, it is not about reaching the truth, but about assigning guilt, or impressing the public, or convincing somebody to change their opinion. In relation to this, Lynch and Bogen make a claim which seems to deserve greater attention than it was met with. This is about the concept of the pre-postmodern situation. According to the authors, we are living in a transitional period, when the actual cultural rules are partially different, yet on account of mental habits, we are still using the models of reasoning and categories which belong, to a great extent, to the past.

Both the idea and the practice of avowal, deriving from the Christian tradition, as well as the ancient and pagan idea and practice of telling the truth, require not only sincerity, but also compliance with the truth. Parrhesia is not only saying what is consistent with our own conviction; this would be insufficient. Parrhesia is also a recognition of the truth, as Foucault tells us in his Berkeley lectures. I play the parrhesia game when I know the truth and I have the courage to announce it. A question emerges: does such an idea and such practice have anything in common, for example, with modern posts on social networking sites or with posts on newspaper websites? Are confessions made on the Internet acts of truth? Provided these are actual confessions and not random confabulation and provided the author is the person whom he/she claims to be, and not somebody else. In 
principle, it is all about making people pay attention to such posts; it is about the number of likes, thumbs up, or down, et cetera. It seems to me that regimes of truth or acts of truth-telling are still important, yet in limited fields of communication. These limited fields, where the message is evaluated in the category of truth, untruth, and lies, are located in a much broader cultural constellation, which comes under, I believe, some other cultural rules, where the criterion of truth is not significant. It seems to me that areas of struggle, a struggle for truth, for differentiation of truth from lies or falsification of reality are particularly valuable today. They show the importance of not following the trend, of speaking the truth, and of confirming the truth with one's own conduct. This is important in multiple areas, including here, in Poland-in education, in the church reality, and in any other reality. I do not wish to sound dramatic, but it is possible that in our times, now, these are particularly important issues, momentous, with a great burden of moral responsibility. Therefore, we should not lose sight of the fact that the general cultural contours have changed. In order to analyze the current cultural transformation, the discourse of truth must be put in inverted commas, and we must see that it is located on the tectonic shift of culture, which is, in principle, anti-Christian as it does not treat the truth and avowal seriously, and it is also anti-ancient because it introduces attention economy instead of truth-telling. And the fact that we, as individuals, experience the reality, sometimes poignantly, yet completely different, and we have our reasons for it, is another issue, which should not foreshadow the fact that apart from our sometimes painful experiences with the immorality or morality of this or another individual, group, community, or institution something else is happening on a broader scale. I would say, possibly too solemnly, that a civilization shift is taking place where such values in which we sometimes deeply be- lieve and are ready to take risks for and testify for, are frequently instrumentalized. They become the symbolic resources for journalistic and political games. They are, we can say, used, reduced to rhetoric, but they are no longer the key cultural rules.

Helena Ostrowicka: Thank you very much, Professor. I would like to invite the rest of you to join our discussion.

Cezary Rudnicki: I have one remark with respect to Professor Czyżewski's standpoint. The interpretation of truth as a certain type of attention management caught my attention. I was not aware of such a thread; it seems very engaging. However, I would like to focus on Foucault because this is my piece of cake. I can see that Professor Czyżewski knows Foucault in depth; however, I am a philosopher who is greatly attached to terminological distinctions, and I am forced to argue with such arbitrary confusion of terms. For Foucault, avowal and parrhesia are not the same. Every time we tell the truth about ourselves, we do it differently, and the truth itself is of a different kind. Avowal is used to speak about one's memories, motivation, and intentions. On the other hand, we use parrhesia to refer to deeds which we actually carry out in life. It seems that we can find a lot of threads or terms in Foucault's writings related to the notion of truth, but they are very clearly distinguished from one another. Obviously, Foucault examines certain transfers and mixtures, but I tend to treat all of these as technical terms with very precise meanings. On the other hand, if we wish to look for the most abstract term, this is what I mentioned during my presentation. It seems that the most abstract manner in which Foucault approaches the truth is to interpret it as a combination of two orders: the spoken order and the order of the visible. During your first speech, you mentioned some tools for analysis, which we are sup- 
posed to find in Foucault's writings. It seems that this is where the analytical potential is embedded. If we examine various systems paying attention to how the discourse is constructed as part of such systems and the visibility structures that are guaranteed, then we will be able to specify how, as part of such a device, or, if you wish, dispositif, truth is understood. For example, when Foucault examines disciplinary societies, he shows that truth there-he still uses the term knowledge-that knowledge there consists of a spoken order, which is an order of regulations and codes, and on the other hand, of a certain order of visibility, primarily architecture, which shows the individual that is located in a subordinate position and hides the ruler, who is in a privileged position. It seems to me that this is the abstract tool, the examination of these two orders and the modes in which they are combined, which may be matched to various devices, various spheres of phenomena, and analyzed thanks to this. I do not know what the situation would be like in the case of modern post-truth. Definitely, it is possible to examine some discourse; it is definitely possible to examine some visibility of those who are using this strategy, but I admit that at the present moment, I do not have an idea how the two could be tackled. Hence, only this concise commentary.

Marek Czyżewski: I will speak very briefly. Thank you very much for these remarks. To what degree does the difference between the spoken and the visible outlined by you help us in analyzing what happens as part of cultural and civilization transformations? Partially it definitely does, but it probably misses the intuition that I have mentioned here several times. I also have an impression that the term "spoken" in comparison with the "visible" leads us to the issue of pre-postmodernity. Isn't it the case that the uttered/visible difference is embedded in the mental horizon related to the category of truth? And
I have already mentioned the over-valuation of the role of truth. Thank you very much.

Helena Ostrowicka: Several threads have appeared in our discussion. Who else would like to speak?

Ryszard Mordarski: I have a question for all of you, which I would like to ask from a slightly more conservative perspective. Are we, living in these modern societies that have clearly been formatted in a neo-liberal mode, not aware that in a certain manner we have already used up all the possibilities, that there is no other move to be made, there is no new alternative? For instance, all the possible games that we could still play have already been played and are beyond us. In this context, one of the key representatives of post-modernism, Zygmunt Bauman, who entitled his last book Retrotopia, speaks up. In a sense, this title symbolically shows the entire situation of exhaustion, even closure of the project of modernity, and slightly teasingly proposes a departure from this situation, offering a return to the past, a focus on the return to what has passed, and re-thinking it anew. Hence, the popularity of all the identity stories today, which are a new method of building the subject, after Foucault's death, of the subject. I would like to refer to what you said, that it will not be possible to build it in a Cartesian way, but we may possibly succeed in some "new" manner, by searching for some personal threads or extensions running into the future and not the past. This would be, to a certain degree, some turning point in post-modernism where the awareness of disappointment with the future and progress is growing, whereas interest is awakened in a return to tradition and its creative exploration. In your opinion, could there be some conservative element in contemporary post-modernism, which emerges from a noticeable disappointment in such experiments as, for example, the death of the subject? 
Maria Mendel: Exactly, I think that we are close to capturing some key sense here... And what you are personally looking for is possibly educational activities in the public space; interruptions of this and not some other shape of relations which we have established and which, in the course of time, have assumed a non-acceptable form. It is important to continue to work for the critical distance enabling articulation of this type. Thank you for this voice.

Ewa Marynowicz-Hetka: I think, that is, I am convinced that insofar as we analyze the past, it is-pardon my expression-useful for us; it explains something to us in the present, and possibly also gives us some elements, some intuition with respect to the past. Simply-it only seems to me-not the past for the sake of the past, analyzed only when it is necessary. There are definitely some disciplines that are only dealing with it, but when we look from the perspective of education, the methodological formula of Gaston Bachelard (2002) fits best, in my opinion.

Ryszard Mordarski: And what about analysis of the past as a method for building a personal identity? In such a case, does the past becomes something valuable in itself, as-to a certain degree-"objective" material, which is meant to provide the "resources" for understanding oneself?

Ewa Marynowicz-Hetka: I am not sure if I can answer.

Maria Mendel: I will answer with Ricoeur: what we create, our narratives, visions of ourselves and the world, individual identity profiles or social profiles, are all fiction. In them, we find our "own" paths of being in the world, existence in the world, and for the world. Maybe this should simply be accepted, and productive constructs should be built on fiction. Today, fearful of tomorrow, has the opportunity to change in these conditions. However, I see a problem elsewhere. WHAT fiction can be pieced together from such bits of the past? What does it say about us today? We who are-metaphorically speaking-opening the door to the future world, where we will no longer be present, only our traces, our heritage, will be there. At the same time, the key issue is: what are we going to say to those who are behind us? Derrida emphatically claims that we are obliged to give testimony, to respond to the spirits that visit us through the traces that we also perceive in ourselves. He emphasizes that we have to do it in the name of justice. For those who are no longer alive, for those who have not yet died, and for those who have not yet been born. This is where the past, the present, and the future are contained. The atmosphere has almost turned church-like. So maybe I will no longer talk about why the return to the past may indicate that we are living in a confessing society.

Helena Ostrowicka: Many questions were asked today and in the course of this panel. These are difficult questions pertaining to education and public space. We have been talking about education since yesterday, referring to Foucault and other non-Foucauldian terms, and we will probably be left with such questions. Would you like to add something at the end of the panel? Professor?

Marek Czyżewski: I really do not know why I should be the one to say something now.

Helena Ostrowicka: We barely heard you yesterday...

Marek Czyżewski: Really, thank you very much for this privilege, but this is also some kind of trap because it is difficult to deliver such a "sermon" now.

Helena Ostrowicka: How about saying something optimistic? 
Marek Czyżewski: Optimistic?

\section{Helena Ostrowicka: Yes...}

Marek Czyżewski: I am not so sure. Since the problem of education has been mentioned, let us take a look at the changes that we are observing, and to which we have, to a significant degree, fallen prey, or which we have perpetrated. In the educational system, at various levels, including in university education, we are starting to live in the fumes of fiction and absurdity. Committees for the quality of teaching operate at every faculty, which are in practice hiding the fact that the quality of teaching is dwindling year by year. Research projects are multiplying, as part of which we often write various things which are, to a great degree, a promise that cannot be fulfilled. New legal and administrative regulations put us in a reality which we also know from other systems and which induce us, I believe so, to choose the traditional path: on the one hand, there is the official, illusory, and, to a certain degree, hypocritical reality, and on the other, there is the truth about such reality. In the previous system, it was impossible to utter such a truth. Now you can do it, but it does not change anything. This is what the difference is about. Nothing bad will happen to us for joking about the authorities, and let's hope that things will stay this way. But, still, this does not change anything. Everybody can say whatever they want to. It seems to me that the reality that surrounds us in the realm of education plainly pushes us to the issue of the politics of truth. It seems to me that in this area of communication the rhetoric of truth, untruth, and lies is continually applied. Yet the basic difference is between how people explicate the reality, that is, what Garfinkel called accountability: which categories and methods are used by peo- ple to interpret a situation, to make it comprehensible for themselves and for others. This is one issue. Another issue is the analysis of the accountability process. I believe that new analytical categories are necessary here. It seems that education is an area in reference to which such categories as: hypocrisy, absurdity, incompatibility with common sense, falsification, self-falsification, pursuing a dubious career, media authority (as distinguished from scientific authority) come to mind. In this area, we are painfully confronted with what is called illusion and with what is called truth. Yet, do we actually explain the reality with the use of such categories as illusion and truth? Or are such categories the tools that we use in order to make the reality comprehensible to ourselves and to others, and we apply such categories because we know them because we have been given them by the cultural tradition-in spite of the fact that maybe something else is happening in our environment which requires a new analytical language, a meta-language allowing for the analysis of the process of accountability. I will only mention one of the possible paths here. It would be worthwhile to check the usefulness of the concept of apparent actions developed by Jan Lutyński in reference to real socialism with respect to the analysis of the functioning of the modern educational system in Poland. It must be added that the identification of apparent actions requires reference to the categories of truth, untruth, illusion, and lies. Therefore, it might turn out that on account of the development of the phenomenon of post-truth, the diagnosis could also be searched for with the use of neo-apparent actions. ${ }^{4}$ But, this is partially a separate issue.

${ }^{4}$ Cf. Jan Lutyński. 1977. "Działania pozorne [Apparent Actions]." Kultura i Społeczeństwo 2:69-78; Marek Czyżewski. 2009. “Neo-Apparent Actions. Some Remarks on Changes of Public Communication and Academic Life." Przegląd Socjologiczny 4:9-30. 
Helena Ostrowicka: Thank you very much, Professor. Such "truth-related" vocabulary may be enhanced with the so-called "tapes of truth"-a tool which is applied for various purposes and in various contexts, and which shows that the role of what was said changes significantly, depending on time and place. Thank you very much for your participation in the panel and the discussion.

Prepared by: Helena Ostrowicka, Justyna Spychalska-Stasiak

\section{Citation}

"Panel Discussion: The Politics of Truth in Education and the Public Space: Discussion at the Opening of the Volume." 2021. Qualitative Sociology Review 17(1):12-26. Retrieved Month, Year (http://www.qualitativesociologyreview.org/ENG/archive_eng. php). DOI: http://dx.doi.org/10.18778/1733-8077.17.1.2 